\title{
Valley downcutting in the Ardennes (W Europe): Interplay between tectonically triggered regressive erosion and climatic cyclicity
}

\author{
A. Demoulin ${ }^{1,2,{ }^{*}}$, A. Beckers ${ }^{1}$, G. Rixhon ${ }^{3}$, R. Braucher ${ }^{4}$, D. Bourlès ${ }^{4}$ \& L. Siame ${ }^{4}$ \\ 1 Department of Physical Geography and Quaternary, University of Liège, Sart Tilman, B11, 4000 Liège, Belgium. \\ 2 Fund for Scientific Research - FNRS, Brussels, Belgium. \\ 3 Institute for Geography, University of Cologne, Germany. \\ 4 CEREGE, University Aix-Marseille III, France. \\ * Corresponding author. Email: ademoulin@ulg.ac.be.
}

Manuscript received: July 2011, accepted: January 2012

\begin{abstract}
While climatic models of valley downcutting discuss the origin of terrace staircases in valleys of middle Europe within the frame of alternating cold and temperate periods of the Quaternary, other models, starting from a base level fall imposed by an initial tectonic signal, describe the response of the drainage network mainly as the propagation of an erosion wave from the place of base level fall (the margin of the uplifted region) toward the headwaters, the two types of model being rarely confronted. In the Ardennes (West Europe), cosmogenic ${ }^{10} \mathrm{Be}$ and ${ }^{26} \mathrm{Al}$ ages have recently been calculated for the abandonment of the Younger Main Terrace (YMT) level, a prominent feature at mid-height of the valleysides marking the starting point of the mid-Pleistocene phase of deep river incision in the massif. These ages show that the terrace has been abandoned diachronically as the result of a migrating erosion wave that started at $0.73 \mathrm{Ma}$ in the Meuse catchment just north of the massif, soon entered the latter, and is still visible in the current long profiles of the Ardennian Ourthe tributaries as knickpoints disturbing their upper reaches. At first glance, these new findings are incompatible with the common belief that the terraces of the Ardennian rivers were generated by a climatically triggered stepwise general incision of the river profiles. However, several details of the terrace staircases (larger than average vertical spacing between the YMT and the next younger terrace, varying number of post-YMT terraces in trunk stream, tributaries and subtributaries) show that a combination of the climatic and tectonic models of river incision is able to satisfactorily account for all available data. The cosmogenic ages of the YMT also point out a particular behaviour of the migrating knickpoints, which apparently propagated on average more slowly in the main rivers than in the tributaries, in contradiction with the relation that makes knickpoint celerity depend directly on drainage area. We tentatively suggest a process accounting for such anomalies in migration rates.
\end{abstract}

Keywords: Fluvial theory, fluvial cyclicity, incision model, river incision, knickpoint propagation, Ardennes

\section{Introduction}

The recent models of Quaternary valley downcutting state that, while a tectonic trigger is indispensable to cause tens of meterdeep incision of bedrock, the cyclic alternation of glacials and interglacials since the mid-Pleistocene revolution ( 1 Ma) is responsible for the development of regionally correlatable terrace staircases in the valleys of recently uplifted areas of middle Europe, in sharp morphological contrast with the Pliocene / Early Pleistocene higher levels of these valleys. In parallel with others (e.g., Bridgland, 2000; Blum \& Törnqvist, 2000; Bridgland \& Westaway, 2008; Gibbard \& Lewin, 2009; Lewin \& Gibbard, 2010), J. Vandenberghe, whose works mainly regard major rivers in large catchments, has significantly contributed to the elaboration and the evolution of these models discussing the climatic forcing of fluvial system development (Vandenberghe, 1993, 1995a, 2002, 2003, 2008). Contrary to older models that strictly related aggradation to cold periods and incision to interglacials (Penck \& Brückner, 1909; Büdel, 1977), diverging also partly from the opinion of 
Gibbard and Lewin (2009), who claim that valley deepening occurred throughout the long-lasting first part of the cold stages, J. Vandenberghe insists on the short duration of the incision episodes, which he places at the transitions between cold and temperate-warm periods (Vandenberghe 1995a, 2008). At these transitions, the imbalance between high efficient discharge and relatively low sediment supply from the hillslopes to the river would be favourable to incision for a short period of time, because of the lagged response to climate variation of hillslope conditions with respect to river discharge. Indeed, while the changing climate induces a rapid change in peak discharge (much higher in cold conditions, mainly as a result of spring snowmelt), the two primary factors determining hillslope erosion, namely the extent of a stabilising vegetation cover and the presence of permafrost, react much more slowly. The latter delay also implies that high frequency climatic variations $\left(\leqslant 10^{3}\right.$ years) are rarely capable of causing recordable changes in river behaviour, that is to say that the time scale of variations is decisive, with most incision episodes resulting from glacialinterglacial-glacial transitions. We note further that all this may also work out at a different pace in small streams directly exposed to variations in hillslope sediment delivery and major rivers where the existence of the floodplain stock of sediment affects the spatial and temporal expression of incision. Moreover, Vandenberghe (2008) suggests that warming transitions cause deep but narrow incision of meandering channels while cooling transitions lead to shallower incision of wide braided systems' floodplains that remove most traces of the preceding incision interglacial deposition event. The chief consequence of this difference in lateral river activity between the two types of climatic transitions is thus to leave only one visible episode of incision for the two successive transitions in the stratigraphic record.

Whichever moment they consider most favourable to incision within a glacial-interglacial cycle, models of fluvial evolution tend to say very little about the spatial distribution of incision and aggradation beyond their respective large-scale link to uplifting and subsiding regions (Lewin \& Gibbard, 2010). Vandenberghe $(1995 b, 2003,2008)$ only notes that, in uplifting areas, incision prevails throughout the glacial cycle as long as the rivers have not reached a steady state. In other words, it is implicitly assumed that the climatically triggered incision episodes were synchronous in large catchment tracts of the ancient massifs of middle Europe that underwent moderate Quaternary uplift. This is anyway the reasoning held for decades in fluvial terrace studies that reconstructed terrace levels mainly on the basis of geometrical correlation, aided whenever possible by mineralogical, petrographical and tephrostratigraphic data, the successive levels being generally ascribed to the cold isotopic stages (e.g., for the Ardennes and the Rhenish Shield, Ek, 1957; Pissart, 1974; Negendank, 1978; Brunnacker \& Boenigk, 1983; Juvigné \& Renard, 1992; Pissart et al., 1997; Rixhon \& Demoulin, 2010). More recently, a still limited set of absolute ages of terrace sediments has come in support of this assumed age continuity at least for middle and low terrace levels along major rivers (e.g., Huxtable \& Aitken, 1985; Losson \& Quinif, 2001; Cordier et al., 2006; Boenigk \& Frechen, 2006).

Meanwhile, leaving the climatic factor aside, a separate corpus of theoretical and empirical studies has been devoted since the 1980's to the response of drainage networks to tectonic uplift (or, more generally, to any relative base level lowering). Although a few numerical models based on the assumption of transport-limited erosion in alluvial rivers, or explicitly incorporating the influence of bed load on bedrock channel erosion, showed that the incision in response to a base level fall could in some cases operate simultaneously along the whole length of the river (Crosby et al., 2007), all physicallybased models of bedrock channel erosion agree to describe the migration of knickpoints or knickzones appearing where the base level change occurs and propagating upstream through the whole drainage network (e.g., Howard \& Kerby, 1983; Sklar \& Dietrich, 1998; Whipple \& Tucker, 1999, 2002). Field studies in various settings repeatedly showed a similar picture of the transient response to uplift materialised by a set of migrating knickpoints, and led to consistent parameterisations of the stream power erosion law used for bedrock channels (Bishop et al., 2005; Crosby \& Whipple, 2006; Wobus et al., 2006; Berlin \& Anderson, 2007; Beckers et al., subm.). Whatever change of shape a knickzone may undergo when travelling across the drainage network (Crosby et al., 2007), the process obviously implies that the former floodplain will be incised diachronically, being abandoned firstly in the lower course of the river and becoming a terrace always later in the upstream direction (Van Balen et al., 2010). Depending on the propagation rate (which is proportional to a power of the contributing drainage area), the knickpoint migration may or may not be completed within the climatically-determined time span favourable to incision of a single glacial-interglacial cycle. As suggested by the available dates for the Meuse, Mosel and Rhine terraces in the Rhenish shield, this will generally be possible along the major rivers, with rates of knickpoint retreat of several meters per year (Loget \& Van Den Driessche, 2009; Demoulin et al., 2012), and the resulting terrace level will then be linked to one particular isotopic stage in these valleys. However, the celerity of the erosion wave decreases rapidly within the smaller catchments of tributaries and subtributaries, making much more probable that a particular terrace level will be of different ages in different places.

These contrasted views about river erosion raise again the issue of the interplay between climate and tectonics in the creation of terrace staircases in the valleys of mid-sized rivers draining uplifted massifs like the Ardennes and the Rhenish shield. How could one separate the part of climate-dependent vertical incision, taking place simultaneously in all streams, from that part linked to longitudinal knickpoint migration, 
which expresses the river response to the tectonic signal? Their respective importance obviously depends on the magnitude of the base level change and the length of the landscape response time, which will interfere with a varying number of climatic incision episodes. Dating terraces in different places of the mid-sized valleys within the massif is therefore crucial to answer this question, and a cosmogenic nuclide study of sediments of the so-called Younger Main Terrace (YMT) in various rivers of the Ardennes (Rixhon et al., 2011) has recently brought results that require to fundamentally revisit the meaning of the Ardennian terraces. The aim of this paper is thus to combine these new age data with an analysis of knickpoints in the current river long profiles (Beckers et al., subm.) in order to discuss their implications in terms of causes and processes of terrace formation in the Ardennes, an area representative of the moderately uplifted regions of middle Europe.

\section{Geomorphological setting}

The Paleozoic Ardennes Plateau is the western continuation of the Rhenish Shield, one of the ancient massifs rising above the NW European platform in front of the Alpine arc (Fig. 1). While its northern limit corresponds more or less to the Variscan front, it is located to the west of the Lower Rhine segment of the European Cenozoic Rift System. Structures inherited from the Caledonian orogeny and deformed again in Variscan times crop out along the axis of the Ardennes, and especially in its northeastern part, resulting in a structurally complex basement wherein longitudinal ENE-WSW folds and thrust faults are cut by numerous NW-SE to NNW-SSE striking normal faults. The bulk of the Ardennes massif is comprised of early Devonian slates surrounding the phyllites and quartzites of Caledonian massifs (the Stavelot Massif in the northeast, the Rocroi Massif in the southwest). Except for local rock resistance contrasts, in particular where quartzitic beds crop out, this chiefly slaty bedrock is fairly homogeneous, giving way to alternating middle and late Devonian sandstones, shales and limestones only in the northwestern part of the massif (the Condroz area).

Numerous studies of the Quaternary terrace staircase in the valleys of the main rivers flowing across the Ardennes and the Rhenish shield (Meuse, Rhine and Mosel), and in those of their tributaries draining the massif agree on the conclusion that uplift of the latter started near the Plio-Pleistocene transition, seemingly in response to far-field stresses (Alpine push and Atlantic ridge opening) and possibly also as a consequence of recent mantle upwelling beneath the nearby Eifel region (Garcia-Castellanos et al., 2000; Ritter et al., 2001; Ziegler and Dèzes, 2007). However, the early Pleistocene uplift rate remained low ( $\leqslant 0.05 \mathrm{~mm} / \mathrm{yr}$, as deduced from river incision rates) until the beginning of the middle Pleistocene, when it suddenly increased to reach maximum values of $\sim 0.5 \mathrm{~mm} / \mathrm{yr}$ in $\mathrm{NE}$ Ardennes and Eifel between 730 and 400 ka before coming back to tectonic quiescence (e.g., Van den Berg, 1996; Hoffmann, 1996; Meyer \& Stets, 1998; Quinif, 1999; Van Balen et al., 2000).

A recent reappraisal of the western Rhenish Shield uplift since $0.73 \mathrm{Ma}$ reduced its maximum amount from previous estimates of $\sim 290 \mathrm{~m}$ (Meyer \& Stets, 2007) to $190 \mathrm{~m}$ in the SE Eifel and modified its general shape, namely stretching and straightening its E-W profile (Demoulin and Hallot, 2009). Although the Rhenish Shield as a whole appears as a broad swell, the topographic contrast between the northern Ardennes and its foreland is more typical of an en-bloc uplift. There, the border faults of the neighboring Roer graben (Fig. 1) accommodate a part of the relative vertical displacement, with estimated $\sim 0.05-0.1 \mathrm{~mm} / \mathrm{yr}$ individual fault motion rates
Fig. 1. Digital elevation model of the western half of the Rhenish shield, centred on the Ardennes and locating the study area (frame of Fig. 3) within the Ardennian part of the Meuse catchment. RVG - Roer valley graben. ECRS (inset) - European Cenozoic rift system.

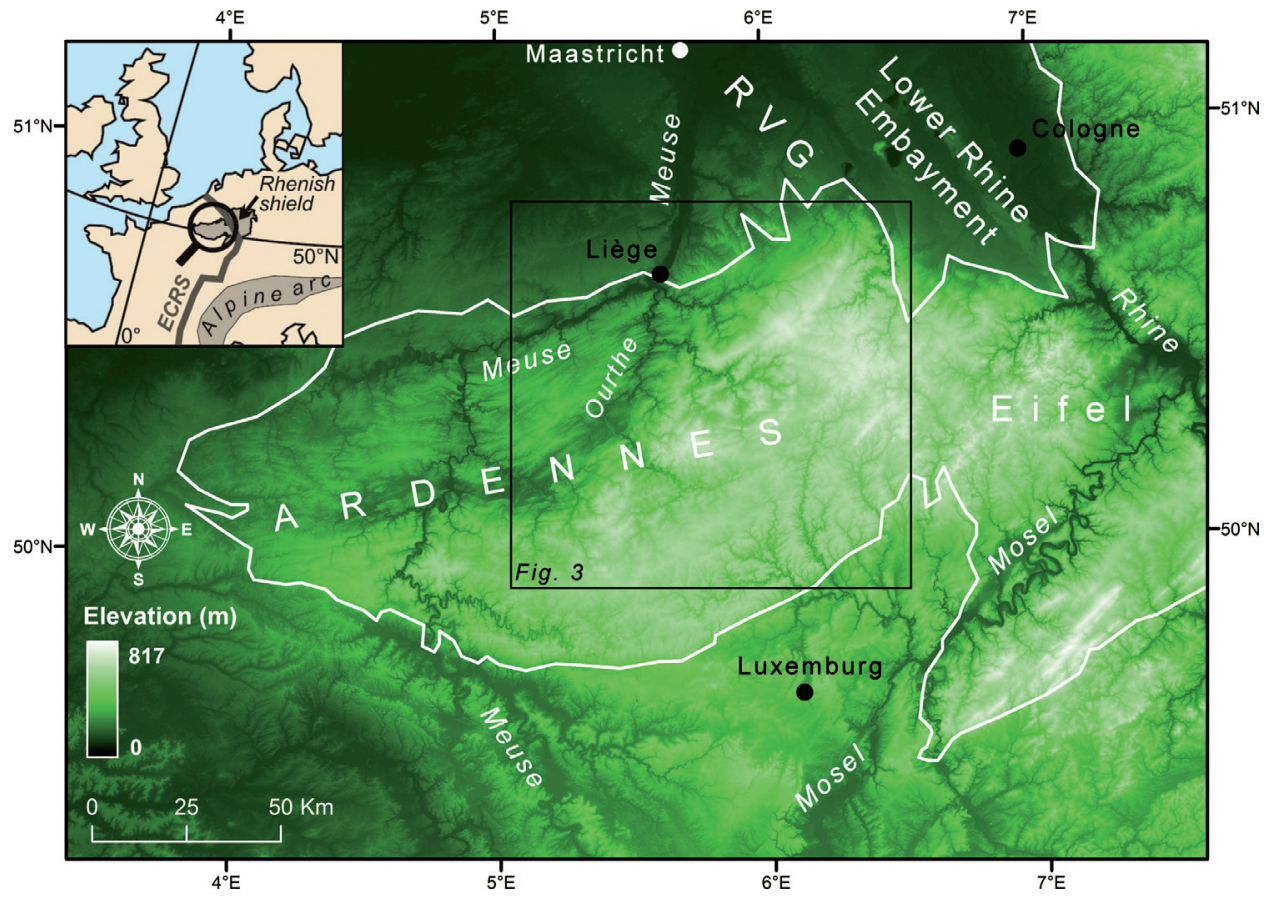


(Camelbeeck and Meghraoui, 1998; Houtgast et al., 2005) while the bulk of the massif uplift is accommodated by a 10- to $20-\mathrm{km}$-wide flexure zone leading rapidly to the remarkably flat interior plateau of the massif (Demoulin, 1995).

Most of the Ardennes Plateau is drained by rivers of the Meuse basin that have incised 100- to 150-m-deep valleys through it since the beginning of the Pleistocene. Terrace studies in the Ardennian rivers have identified a flight of 10-15 levels along the main streams, reducing to 6-7 in their upstream reaches and to 1-3 levels in smaller tributaries (e.g., Cornet, 1995; Pissart et al., 1997). As a consequence of the middle Pleistocene increase in incision rate, valleys in the Ardennes display a typical cross-section that opposes a narrow, steep-sided young valley nested into a broader older valley with gently sloping valleysides carved into the Tertiary paleotopography (Fig. 2). Dated $\sim 0.73 \mathrm{Ma}$ at the massif's northern margin (Van Balen et al., 2000; Boenigk and Frechen, 2006; Rixhon et al., 2011), the extended lower level of the Main Terrace Complex (YMT) clearly separates the two units and marks the beginning of the middle Pleistocene incision episode. The YMT is the best preserved terrace in most Ardennian rivers and it is commonly believed that, as a climatic terrace, it is of the same age everywhere in the massif. Below this key level, a maximum of 5 much narrower younger terraces is more or less well preserved, bearing witness to the vigor of the post-YMT incision.
We focus here on the drainage system of the Ourthe River, the main tributary of the Meuse River in the Ardennes (Fig. 1). Its highly asymmetric catchment extends over $3600 \mathrm{~km}^{2}$ of central and NE Ardennes, with a 150-km-long main stem flowing from south to north very close to the catchment's western border and two E-W flowing main tributaries, the Amblève and the Vesdre, which drain the most elevated area (up to $700 \mathrm{~m}$ ) of the massif (Fig. 3). The Ourthe River flows into the Meuse River at Liège, which, at $55 \mathrm{~m}$ asl, makes a regional base level located approximately at the border of the uplifted massif.

\section{New data and age constraints on river incision}

The sharp transition from wide to narrow steep-sided valley cross-profiles at the YMT level represents the river response to an abrupt increase in uplift rate, a response that most probably occurred through the propagation of an erosion wave in the Ardennian drainage network. Indeed, the Tertiary planation surfaces extending over the massif are only faintly tilted (Demoulin, 1995; Demoulin \& Hallot, 2009), indicating that the mid-Pleistocene uplift occurred mostly en-bloc and the base level change it imposed to the rivers was confined, especially along the massif's northern margin, to a narrow zone where knickpoints formed in the river profiles before propagating towards the massif's interior. In a study of knickpoints in the
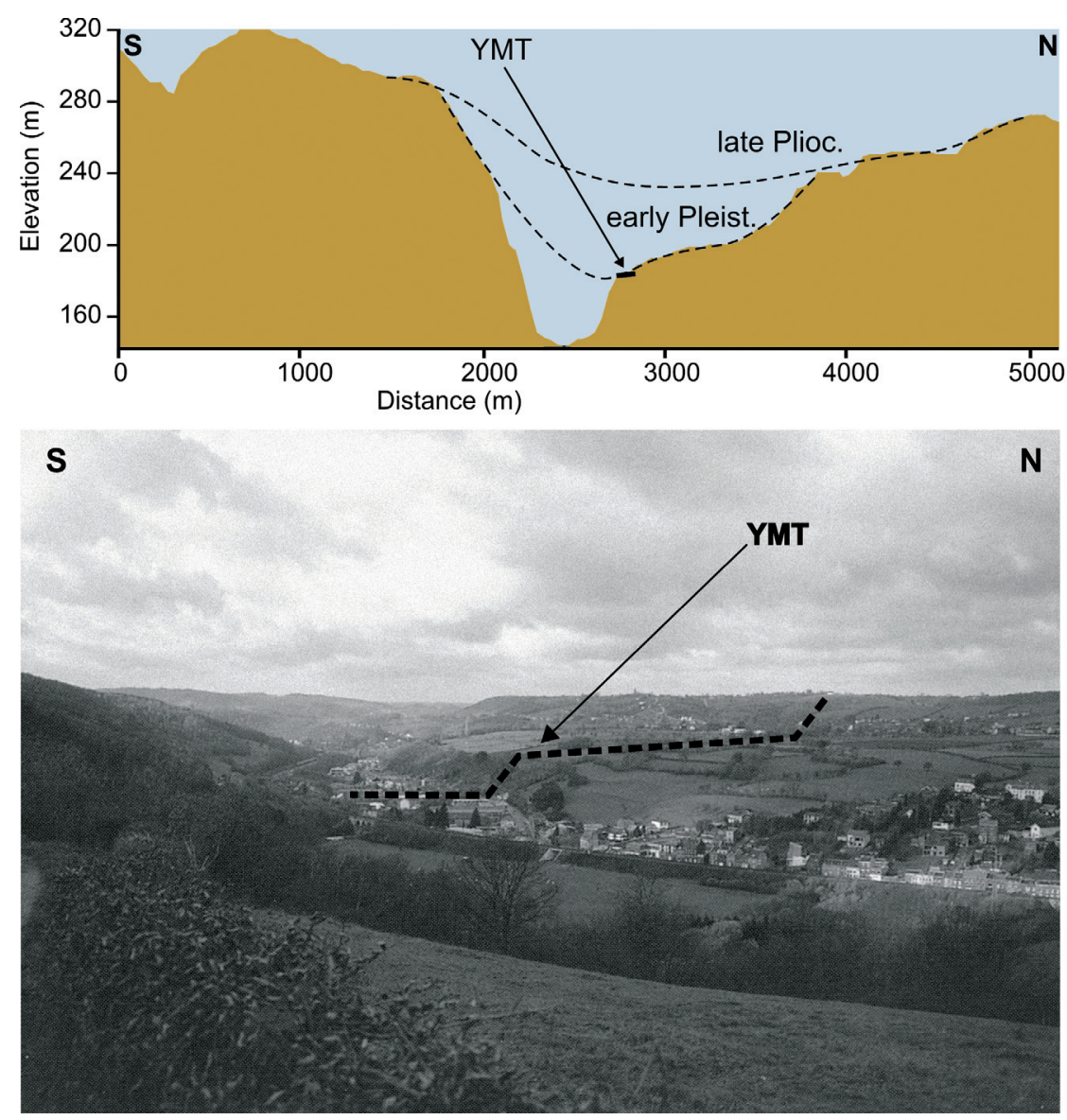

Fig. 2. Cross-profile and photograph of the Vesdre valley, a typical Ardennian valley, downstream of Verviers (see location on Fig. 3), showing the nested late Pliocene, early Pleistocene, and narrow post-YMT valleys. The YMT represents the last floodplain developed within the broad early Pleistocene valley before abrupt incision and valley narrowing started at $0.7 \mathrm{Ma}$. 
Fig. 3. New data about the migration of a post-YMT erosion wave within the Ourthe catchment (outlined in white). Stars locate sites of cosmogenic ${ }^{10} \mathrm{Be} /{ }^{26} \mathrm{Al}$ dating of alluvial gravels of the YMT (ages in ka). Large black dots denote knickpoints that reliably locate the positions reached by the post-YMT erosion wave in the present-day river profiles. Smaller white dots are for other knickpoints, either of lithological origin or at least not fully reliable as indicators of the post-YMT erosion wave.

Ourthe drainage network, Beckers et al. (subm.) were able to prove that the post-YMT incision proceeded that way. They showed that, beyond lithologically controlled profile irregularities, 18 knickpoints identified in the present long profiles of the Ourthe and its tributaries and subtributaries are located in upstream river reaches where the YMT profile merges into the current river profile (Fig. 4), thus locating the points reached by the post-YMT erosion wave after having travelled for $\sim 0.73 \mathrm{My}$ (Fig. 3). Justifying their use of a bedrock river incision model by the fact that the incising rivers cut rapidly through their former floodplain, thus disconnecting their channels from the alluvial cover and inscribing them in the bedrock, they fitted a knickpoint celerity model derived from a simple expression of the stream power law (Whipple \& Tucker, 1999) to the distribution of the knickpoint data and found that the adjustment was fairly good, with a mean distance residual (between observed and modelled knickpoint positions) of $\sim 0.8 \mathrm{~km}$ and a standard deviation of the residuals of $2.3 \mathrm{~km}$ (to be compared with knickpoint travel distances up to $145 \mathrm{~km}$ ). The resulting parameterisation of the stream power law yielded $\mathrm{m} / \mathrm{n}$ (the ratio between the exponents of contributing drainage area and channel gradient) $=0.75$ and $\mathrm{K}$ (the erosivity coefficient) $=4.610^{-8} \mathrm{~m}^{1-2} \mathrm{my}^{-1}$, which is consistent with theoretical values and quite in the range of values derived elsewhere (Bishop et al., 2005; Berlin \& Anderson, 2007). Moreover, Beckers et al. (subm.) showed that the model residuals $5^{\circ} 30^{\prime} \mathrm{E}$
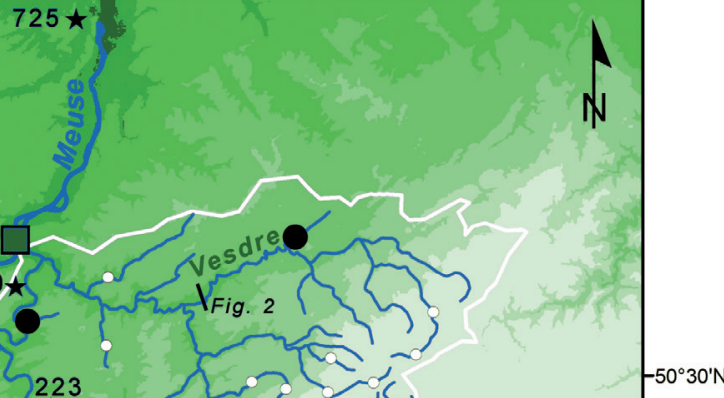

223

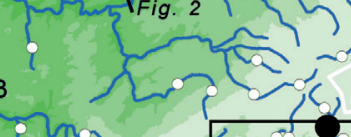

?
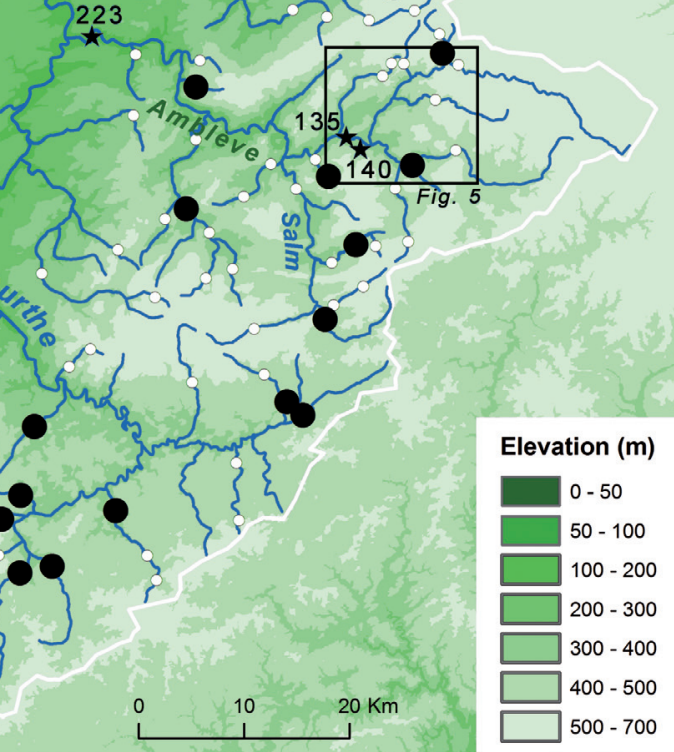

were significantly correlated to a descriptor of the importance of the tributary junctions passed over by the knickpoints. This correlation pointed to a delay in the propagation of erosion at junctions, in proportion to the relative change in catchment relief and channel gradient when going from the trunk stream to the tributary. Much as it has been observed for the hanging valleys of Taïwan (Wobus et al., 2006), such delays were especially long for knickpoints entering the smallest streams, even though they rarely steepened to waterfalls in the Ourthe catchment. While no clear physical understanding of this observation is so far available, many more parameters than just drainage area, already included in the erosion law, change abruptly at junctions, namely channel gradient, amount and calibre of bed load, channel form and width/depth ratio, possibly also the erosion processes (abrasion, plucking, cavitation), which might impose thresholds in knickpoint migration.

Another study carried out in the same area recently furnished age constraints on the formation of the YMT within the Ardennes massif (Rixhon et al., 2011). Initially, this study aimed to provide YMT dates along the Amblève River, where three sites were investigated by sampling vertical profiles in terrace sediments in order to establish curves of depthdependent concentrations in cosmogenic ${ }^{10} \mathrm{Be}$ and ${ }^{26} \mathrm{Al}$ (Fig. 3). One site was located in the lower Amblève, the two others some $50 \mathrm{~km}$ more upstream, in the middle Amblève. The modelled exposure ages were highly surprising as they consistently 


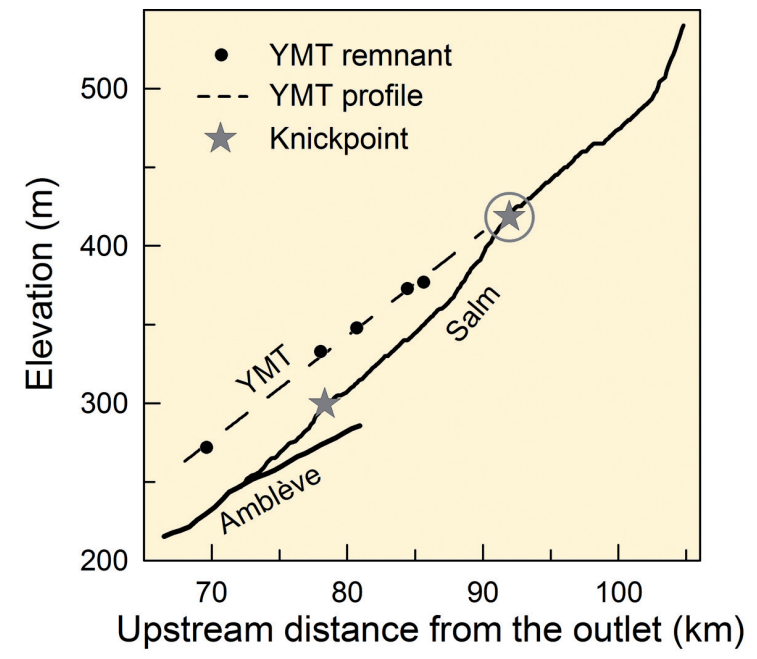

Fig. 4. Long profile of the Salm River (see location on Fig. 3) showing the relation between the upstream end of the reconstructed YMT profile and the knickzone in the present-day profile that materialises the point currently reached by the erosion wave in this valley (circled star).

indicated that the YMT had been abandoned only $223 \pm 31 \mathrm{ka}$ ago in the lower Amblève, and $140 \mathrm{ka}$ ago in the middle Amblève, whereas the previously available paleomagnetic estimates of the Meuse YMT age in the Maastricht area exceeded $700 \mathrm{ka}$, whatever their interpretation (Felder et al., 1989; Van den Berg, 1996; Van Balen et al., 2000). Consequently, further profiles were sampled in YMT sites of the lower Ourthe and the lower Meuse in order to track the terrace age evolution along the Meuse-Ourthe-Amblève drainage line, starting from the area where paleomagnetic measurements had been carried out before. The new ${ }^{10} \mathrm{Be} /{ }^{26} \mathrm{Al}$ dates obtained at Romont/Eben-Emael in the lower Meuse and Colonster in the lower Ourthe fully confirmed that the YMT formed diachronically along this axis, as Rixhon et al. (2011) obtained a modelled cosmogenic age of $725 \pm 120 \mathrm{ka}$ at Romont, in agreement with the paleomagnetic data of the same area, and $390 \pm 35 \mathrm{ka}$ in the lower Ourthe. The age differences between the sites are well beyond the analytical and modelling errors (higher only at Romont because of the uncertainty inherent in the modelling of the burial effect by a superincumbent loess cover). Moreover, the cosmogenic nuclide measurements in the Belle-Roche site of the lower Amblève revealed a specific concentration profile for this anomalously thick terrace deposit. By contrast with the usually 3-m-thick alluvial cover of terraces in the Amblève and other Ardennian valleys of the same size, the Belle-Roche YMT alluvial gravels are more than $7 \mathrm{~m}$ thick and show a bipartite ${ }^{10} \mathrm{Be}$ curve, with concentrations decreasing exponentially with depth as usual in the three upper meters of the profile, and then increasing systematically with depth between $3 \mathrm{~m}$ and the bottom of the profile at $6.5 \mathrm{~m}$. The lower part of the profile has been interpreted by Rixhon et al. (2011) as resulting from a very slow accumulation of the terrace deposits by long-lasting aggradation. Their modelling of this aggradation episode indicated that the YMT deposit at Belle-Roche started to form at least $580 \mathrm{ky}$ ago, thus most probably not much later than in the Maastricht area. This supports to some extent the geometrical relationships linking remnants of the YMT throughout the Meuse basin but, at the same time, suggests that the formation of the YMT floodplain too suffered some degree of diachronism between lower Meuse and Amblève.

\section{Modes and timing of the incision}

The diachronism of the abandonment of the YMT along the Meuse-Ourthe-Amblève drainage line is consistently supported not only by the cosmogenic ages of the terrace deposits (Rixhon et al., 2011) and the location of the present-day knickpoints identified by Beckers et al. (subm.) in the Amblève headwaters, but also by the approximate location of another stage of the erosion wave progression along the Eau Rouge River, a tributary of the Amblève (Table 1). Until the end of the Eemian, the Eau Rouge valley was occupied by the Warche River, whose upstream half was then captured by a small tributary of the Amblève at Bévercé (Fig. 5). In the abandoned section of its former valley, the reconstructed long profile of the Paleowarche displays at Bernister a prominent convexity buried under the 40-m-thick post-capture valley filling (Pissart \& Juvigné, 1982). Considering its amplitude, this convexity most probably

Table 1. Time tags of the migrating erosion wave triggered by the pulse of uplift of the Ardennes at 0.73 Ma. The Romont-Maastricht area is located at the northern margin of the uplifted massif.

\begin{tabular}{|c|c|c|c|c|c|}
\hline & River & Data & Distance from Maastricht (km) & Age (ka) & Drainage area $\left(\mathrm{km}^{2}\right)$ \\
\hline Romont & lower Meuse & ${ }^{10} \mathrm{Be}+{ }^{26} \mathrm{Al}$ & 6 & $725( \pm 120)$ & 20976 \\
\hline Colonster & lower Ourthe & ${ }^{10} \mathrm{Be}+{ }^{26} \mathrm{Al}$ & 30 & $390( \pm 35)$ & 2914 \\
\hline Belle-Roche & lower Amblève & ${ }^{10} \mathrm{Be}$ & 55 & $223( \pm 31)$ & 1072 \\
\hline Stavelot & middle Amblève & ${ }^{10} \mathrm{Be}$ & 101 & $135( \pm 6)$ & 465 \\
\hline Lodomez & middle Amblève & ${ }^{10} \mathrm{Be}$ & 103 & $140( \pm 10)$ & 264 \\
\hline Bernister & Paleowarche (Eau Rouge) & buried knickpoint & $111-113$ & $50-78$ & 151 \\
\hline Robertville & Warche & knickpoint & $120^{*}$ & 0 & 106 \\
\hline Ligneuville & upper Amblève & knickpoint & 116 & 0 & 115 \\
\hline
\end{tabular}

* The true value is $123 \mathrm{~km}$, but the Warche capture reduced by $3 \mathrm{~km}$ the distance the knickpoint had to travel to its present location in the Warche valley. 


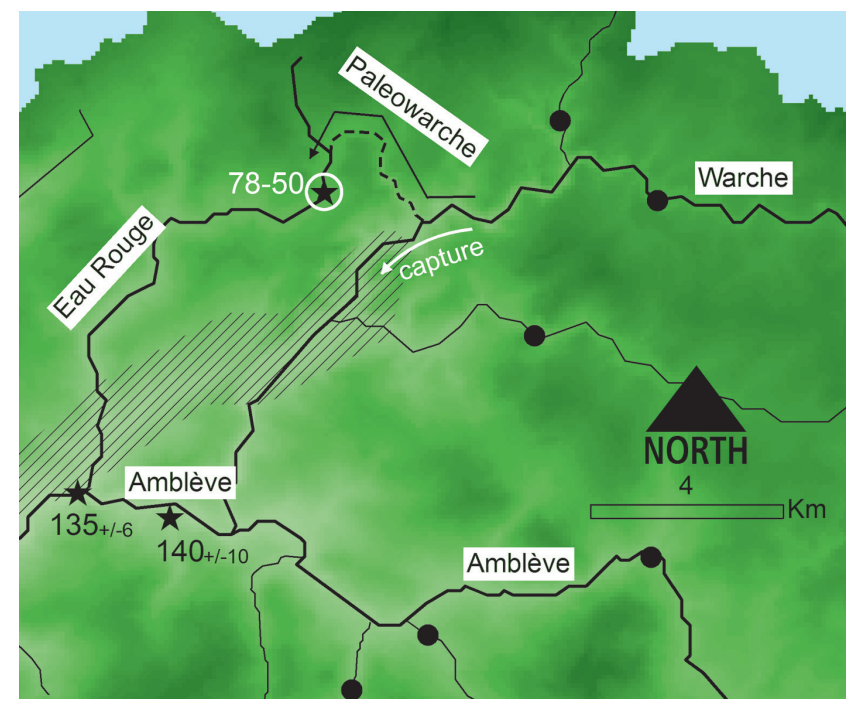

Fig. 5. Sketch map illustrating the Warche capture (see location on Fig. 3). The dashed line marks the ancient course of the Warche, continued by the course of the present Eau Rouge. Stars indicate dated positions of the retreating post-YMT knickpoint (in ka, with $1 \sigma$ uncertainty for the cosmogenic ages along the Amblève). The circled star locates the buried knickpoint of the Paleowarche in its pre-capture course. Black dots denote post-YMT knickpoints in the current river profiles.

corresponds to the post-YMT knickpoint and marks the place it had reached at the time of the capture. After the capture, the last alluvial deposits accumulated by the Warche in its former valley were rapidly sealed by a thin peat layer overlain by lacustrine clays. Dating opportunities were provided by the peat layer, with a pollinic assemblage typical of a cold period and an age beyond the ${ }^{14} \mathrm{C}$ dating limit of 50 ka (Juvigné \& Schumacker, 1985). Moreover, minerals of the Rocourt tephra dated between 90 and $74 \mathrm{ka}$ (Pouclet et al., 2008; Lenaz et al., 2010) were found within the alluvial gravels below the peat. All this indicates that the capture, and therefore also the time when the erosion wave had reached Bernister, occurred during MIS 4, at some time between 78 and $50 \mathrm{ka}$.

At a larger scale, the knickpoints distributed throughout the Ourthe catchment locate the present front of the post-YMT erosion wave, confirming that the latter still proceeds, though at idling rate, towards the Ardennian headwaters. It follows that, at any time since $0.73 \mathrm{Ma}$, the stream reaches upstream of the knickpoints were unable to develop terrace staircases associated with glacial-interglacial cycles up to the time when the erosion wave reached them. In particular, this is verified for the present day as the YMT profiles connect with the current long profiles at the height of the knickpoints, leaving no place for a younger terrace to exist upstream of the knickpoints.

Similarly, in the river courses already travelled by the erosion wave, it seems there is a theoretical incompatibility between knickpoint migration and the existence of a flight of middle and lower terraces below the YMT, which rather suggests gradual vertical incision (Crosby \& Whipple, 2006). However, the observed vertical spacing between the YMT and the next younger terrace is systematically larger than the average spacing between successive terraces in the Ardennian valleys. This larger spacing just below the YMT is in fact indicative of the height of the migrating knickzone, which progressively decreased from $\sim 20 \mathrm{~m}$ in the lower Meuse between Maastricht and Liège to $\sim 15 \mathrm{~m}$ in the lower Ourthe and $12-15 \mathrm{~m}$ in the Amblève. Moreover, taking the progressively lowering Meuse channel at Liège, where it leaves the massif, as the reference base level, the time of the YMT abandonment in a particular place of the Ardennian drainage network should determine the maximum incision that could be caused by the migrating knickpoint in that place. For instance, when the knickzone was passing at Colonster, in the lower Ourthe, $390 \mathrm{ka}$ ago (i.e., during the incision episode associated with the transition from MIS 11 to 10), the Meuse River was going to develop the floodplain that would later become the terrace of Caberg 2, 35 $\mathrm{m}$ below the YMT in the Liège area (Juvigné \& Renard, 1992), and this $35 \mathrm{~m}$ maximum incision possible at this time in the Meuse-Ourthe-Amblève system is indeed consistent with the observed $15 \mathrm{~m}$ vertical erosion that resulted from the passage of the erosion wave in the lower Ourthe (Fig. 6). Still more importantly, the time needed by the regressive erosion to reach tributary streams within the massif should have had direct consequences on the number of middle and lower terraces that these streams were able to develop below the YMT. Again, this implication is satisfied by the field data: while 8-9 terrace levels were formed below the YMT since $0.73 \mathrm{Ma}$ in the lower Meuse (Van den Berg, 1996), only 5-6 levels were formed since $390 \mathrm{ka}$ in the lower Ourthe (Cornet, 1995) and 4 levels in the Amblève since $220 \mathrm{ka}$ (Rixhon \& Demoulin, 2010), in good agreement with the number of periods climatically favourable to erosion in the respective time spans. In summary, all data of the terrace staircases of the Meuse, Ourthe and Amblève valleys perfectly fit in with the picture of the post-YMT erosion wave propagating through the Ardennes drainage network evidenced by the YMT cosmogenic ages and the observed knickpoints in the river profiles.

Unfortunately, while it is now firmly established that the YMT was abandoned diachronically in the Ardennian valleys, very few independent chronological data are available for the younger terraces of these same valleys, leaving the question of their mode of formation partly unresolved. Such data concern mainly the presence of the Weichselian Rocourt and Laacher See tephras in terrace deposits and suggest that the lower terraces have essentially the same age everywhere in the Ardennian drainage system, in compliance with the climatic scheme of terrace formation (Juvigné, 1979). As far as the middle terraces are concerned, IRSL ages of terrace sediments of the Meurthe River (Cordier et al., 2006) combine well with OSL and IRSL data in the Mosel valley in Luxemburg (Cordier et al., 2010) and an U/Th age in the upper Mosel (Losson \& Quinif, 2001) to suggest that they have uniform ages throughout the 


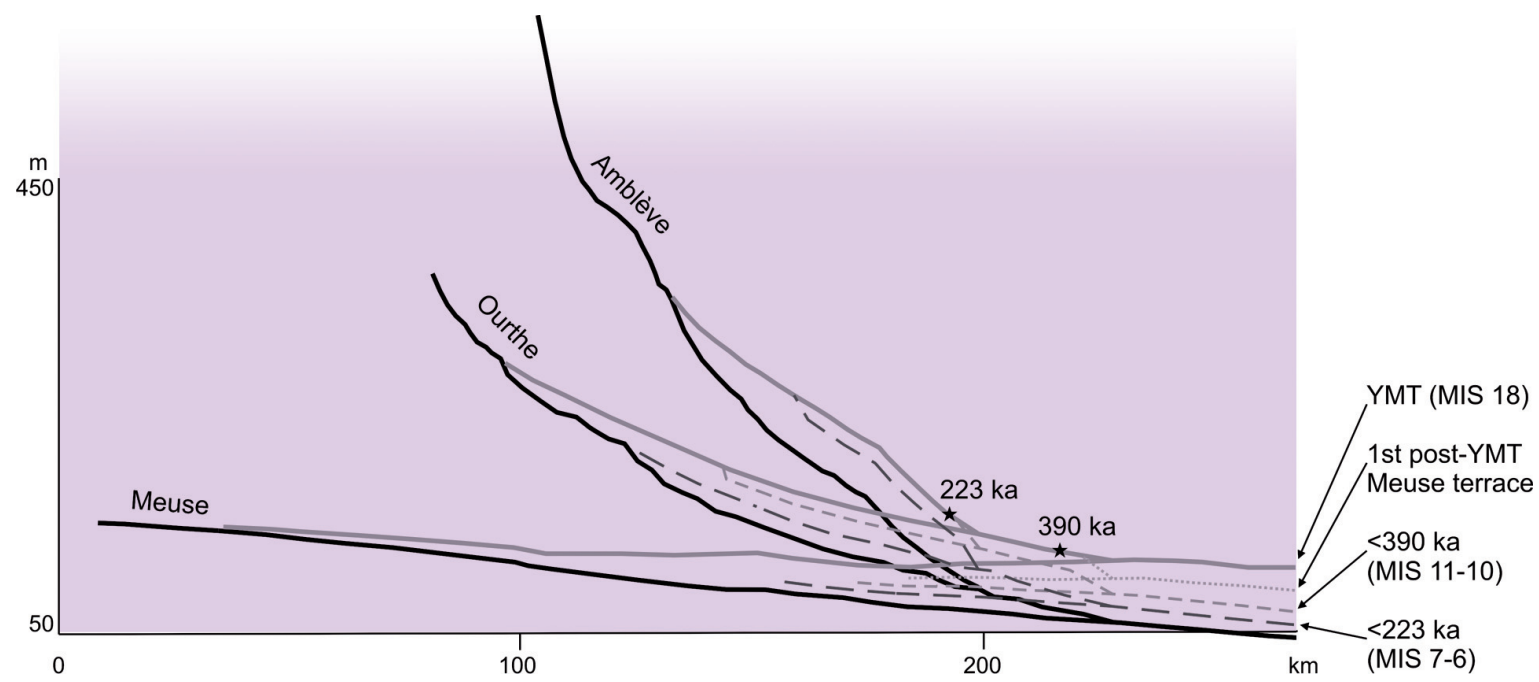

Fig. 6. Long profiles of the Meuse-Ourthe-Amblève drainage system at 725 (starting time of the YMT formation in the Maastricht-Romont area), 620 (= MIS 16, time of the first post-YMT Meuse terrace between Maastricht and Liège), 390, 223 and 0 ka, showing the progressive knickpoint retreat towards and within the smaller tributaries. The black and grey bold lines respectively represent the current and YMT long profiles. The stars locate and give the age of the sites dated by cosmogenic nuclides in the Ourthe (Colonster, $390 \mathrm{ka}$ ) and the lower Amblève (Belle-Roche, $223 \mathrm{ka}$ ). Not all post-YMT terrace levels are drawn in this schematic illustration, which however clearly evidences that these levels are less numerous in tributaries than in trunk streams.

Mosel catchment (Fig. 1). Although the Mosel is a major river that originates outside the uplifted massif and might be thought to be able to propagate an erosion wave along its entire course within one single glacial-interglacial cycle, many of the age data refer to the upper part of its catchment where the concerned drainage areas are by no means larger than those of the purely Ardennian rivers. Thus, despite the absence of age data for the middle terraces of the latter, we make the provisional assumption that they were created in a way similar to the lower terraces, with which they share all their morphological features.

\section{A new model of valley downcutting combining the effects of climate and uplift}

This leads us to propose a new evolutionary model for the midPleistocene deepening of the Ardennian valleys. After the wide Early Pleistocene valleys had reached a steady state at the time of the YMT, a tectonic impulse raised the Rhenish shield and the Ardennes and triggered a wave of regressive erosion that began to propagate within their drainage network around $0.73 \mathrm{Ma}$. The age of this impulse is estimated not only from the incision history of the massif, but also from the concomitant occurrence of the Quaternary volcanism of the Eifel (Schmincke, 2007) and the deformation of terrace profiles along major rivers (Pissart, 1974; Cordier et al., 2006). The transient response of the drainage system operated thus longitudinally by knickpoint migration rather than vertically by ubiquitous profile incision. However, once the knickzone had travelled up stream reaches, the latter kept on deepening each time the climatic conditions were propitious to fluvial erosion, but then after the climatic fashion of simultaneous vertical incision in the whole part of the drainage network situated downstream of the positions reached by the erosion wave. Indeed, after the tectonic impulse at the beginning of the middle Pleistocene had imposed uplift rates up to $0.3 \mathrm{~mm} / \mathrm{y}$ in NE Ardennes, the rates rapidly decreased to less than $0.1 \mathrm{~mm} / \mathrm{y}$ during the middle Pleistocene and only $0.02 \mathrm{~mm} / \mathrm{y}$ in the late Pleistocene (Van Balen et al., 2000), giving the drainage network every latitude to progressively return to a new steady state. A simple calculation of the isostatic response to erosion based on the eroded volume estimates of Demoulin et al. (2009) even suggests that, at the scale of the Ourthe catchment, the present-day tectonic component of uplift would almost equal zero. Whittaker et al. (2008) recently showed that the longitudinal profile of rivers intersected by an active dip-slip fault in the Central Apennines displays a knickzone only if the fault has undergone an increase in slip rate within the last $1 \mathrm{My}$, whereas it keeps a steady state, uniformly concave-up shape when incising under constant fault slip rates since a longer time. This observation supports the conclusion that, even if the uplift pulse that started at $0.73 \mathrm{Ma}$ in the Ardennes had lasted for more than one period of climatically triggered fluvial erosion, it would have generated a single wave of regressive erosion.

Consequently, at every time since the onset of the midPleistocene uplift of the massif, the Ardennian drainage network has been divided in three parts of distinct erosional behaviour: (1) the knickzones travelling up the branches of the drainage network and representing the transient response to uplift, where incision results from the longitudinal displacement of the erosion wave, (2) the regions downstream of the knickzones, where the river profiles progressively achieve equilibrium by ubiquitous vertical incision, and (3) the upstream regions not yet attained by the knickzones, where the whole landscape, valleys and interfluves, is still in steady 


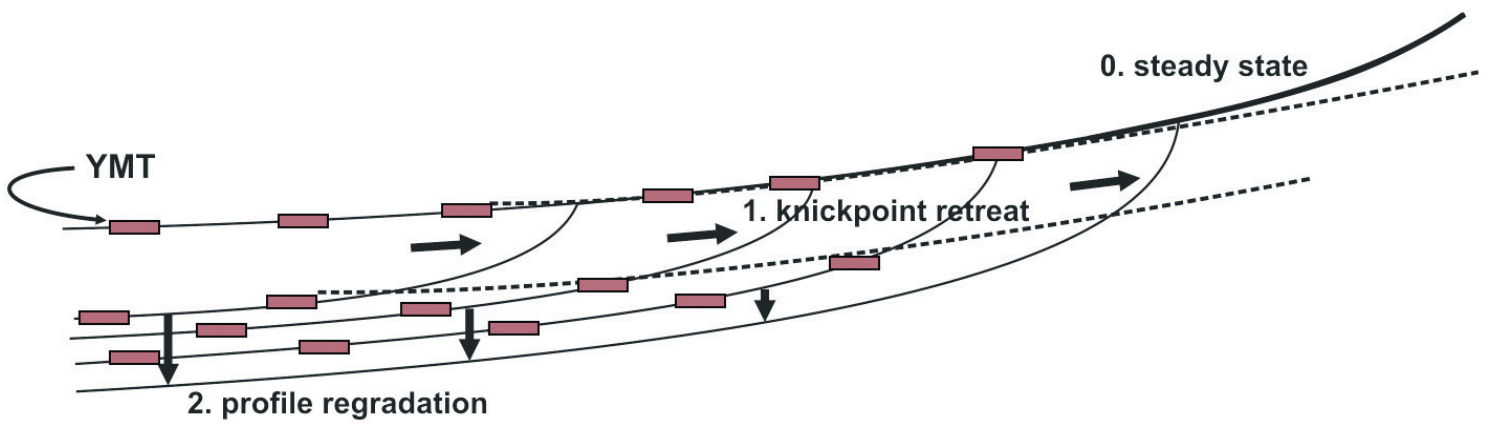

Fig. 7. Schematic illustration of the terrace staircase created by and after the propagation of an erosion wave, with a higher vertical spacing between the first two terrace levels reflecting the height of the migrating knickpoint, then general incision from the part of the profile situated downstream of the knickzone. From source to outlet, three parts of the profile with specific erosional behaviour are distinguished: (0) upstream of the knickzone, extremely slow general incision at steady state, (1) at the height of the knickzone, erosion linked to the propagating knickpoint, and (2) downstream of the knickzone, gradual return to equilibrium by general vertical incision. YMT = Younger Main Terrace of the Ardennian rivers. The stippled rectangles represent alluvial deposits preserved as terraces.

state under very low denudation rates, so that the river long profiles inherited from the Early Pleistocene, and the valley transverse profiles as well, maintain their shape unchanged.

Whatever the assumed model of climatic fluvial erosion (Vandenberghe, 2008; Bridgland \& Westaway, 2008; Gibbard \& Lewin, 2009), it still constitutes the temporal frame determining the periods favourable to incision within a glacial-interglacial cycle. During glacials, the whole drainage system, up to the smallest streams, was cluttered up with hillslope material, so that bedrock channel erosion, in other words knickpoint propagation, was temporarily impeded. This is basically the way climate variations interacted with uplift-triggered regressive erosion to yield the observed temporal and spatial patterns of river terraces within the massif. In this frame, the periods of active knickpoint retreat were probably somewhat longer than those which enabled general profile incision, as the higher channel gradients and the often associated reduced channel width (Attal et al., 2008) increase the stream power locally at knickzones. However, most knickpoints described by Beckers et al. (subm.) in the Ourthe catchment display gravelbed channels and are presently inactive, highlighting that the erosive power of the Ardennian rivers is extremely weak also during the interglacials.

\section{Anomalies in knickpoint migration rate}

The new cosmogenic age and knickpoint data also allow considerations about knickpoint migration rates. Based on the present-day position of the erosion wave, the model fitting of Beckers et al. (subm.) yielded for instance celerity values of $2.7 \mathrm{~m} / \mathrm{y}$ in the lower Meuse, $\sim 0.7 \mathrm{~m} / \mathrm{y}$ in the lower Ourthe, and between 0.1 and $0.3 \mathrm{~m} / \mathrm{y}$ in the Amblève, consistent with what has been derived elsewhere (Loget \& Van Den Driessche, 2009). One can also calculate average migration rates for the stream reaches comprised between adjacent sites dated by the cosmogenic nuclides along the Meuse-Ourthe-Amblève line.
This apparently gives very low retreat rates in the main rivers, namely $0.07 \mathrm{~m} / \mathrm{y}$ from Romont to Colonster and $0.15 \mathrm{~m} / \mathrm{y}$ from Colonster to Belle-Roche, contrasting with a higher rate of $0.52 \mathrm{~m} / \mathrm{y}$ in the Amblève between Belle-Roche and Stavelot. Still more upstream, the knickpoint retreat rate through resistant arkoses in the Warche valley since the capture amounts to $\sim 0.1 \mathrm{~m} / \mathrm{y}$. However, one should remember that all these values are based on the assumption of temporally continuous erosion, and they should probably be multiplied by a factor 2 to 4 if one admits that only $25-50 \%$ of the time of a glacial-interglacial cycle offered climatic conditions favourable to fluvial erosion.

In any case, the magnitudes obtained for the knickpoint average celerity in the Ardennes based on cosmogenic data show an unexpected contrast between low rates in the lower Meuse and the lower Ourthe and higher rates in the Amblève, where the knickzone had moreover to carve its way through the resistant quartzites of the Quarreux gorge. Obviously, the respective drainage areas should have entailed the opposite rate balance (Table 1). In particular, as the absolute rates in the Meuse and the Ourthe are especially much too low, the only distinctive feature of the Romont-Colonster and ColonsterBelle-Roche stretches that might have caused in some way such low figures appears to be the passage of the knickzone from a trunk valley into a much smaller tributary, with drainage area ratios amounting respectively to 0.17 and 0.39 at the Meuse-Ourthe and Ourthe-Amblève junctions. The low average rates would then result from temporary stops of the knickzone at these junctions. This should be compared with the finding of Beckers et al. (subm.) that their model residuals were correlated with the index values assigned to the junctions passed over by the knickpoints currently observed in very small tributaries. However, we deal here with junctions between streams of higher orders, which a priori should reduce the contrast, and thus also the potential impact of thresholds in variables other than drainage area over the passage of junctions by 15 - to 20 -m-high knickpoints. Therefore, noting that, in 
larger streams, a migrating knickpoint proceeds toward an initially alluvial channel that will often give way to a bedrock channel within the knickzone, we tentatively propose as a working hypothesis that the propagation of the erosion wave within an alluvial tributary might be temporarily delayed because the tributary, rather than transmitting the erosion signal upstream, would be able to absorb the high gradients more readily than the trunk stream, e.g. by an increase in channel sinuosity within the floodplain (Ouchi, 1985). As an example, a 15-m-high knickpoint transmitted by an hypothetical erosion wave might be absorbed by doubling the sinuosity of the $1.2 \%$-steep channel of the Ourthe over a reasonable stream length of $\sim 12 \mathrm{~km}$, whereas erasing the original $20 \mathrm{~m}$ height difference within the same length of the $\sim 0.47 \%$ o-steep channel of the Meuse would require an improbable 4.5-fold increase in sinuosity. Channel form modifications in the lower reach of an alluvial tributary would thus locally take over from knickpoint migration in the system's response to uplift, and slow the propagation of erosion down or even stop it for a while. Only the continuation of the trunk stream incision might then finally overshoot the capacity of the tributary to respond by sinuosity change and restart the propagation of a knickpoint in this tributary. As we suspect that much of the increased sinuosity could be lost again once incision has finally cut through the tributary floodplain, thus leaving few traces in the morphology (though there are faint indications of increased sinuosity in the lowest courses of the Ourthe, the Amblève, and some larger tributaries of the latter), as also the current numerical models of fluvial erosion hardly take into account lateral erosion and struggle to reproduce the evolution of meandering, the hypothesis on the role of sinuosity change in delaying knickpoint migration probably might be best tested by analogue modelling in flumes. Besides, a detailed theoretical analysis of the impact of abrupt changes in bed load amount and size with respect to those in channel geometry and form should also shed light on their complex interplay and on the resulting relative propensity to vertical or lateral erosion of trunk stream and alluvial tributary at junctions, potentially responsible for strongly delaying or even temporarily stopping the migration of knickpoints at the mouth of alluvial tributaries significantly smaller than the trunk stream.

\section{Conclusions}

We have shown that the classical models of climatically triggered Quaternary valley downcutting in middle Europe in general and the Ardennes in particular are not able to explain new cosmogenic ages of the YMT that demonstrate a diachronic abandonment of this terrace in the Ardennes drainage network. The propagation of a post-YMT erosion wave in the Ardennian fluvial system is moreover supported by the presence of knickpoints still affecting the river long profiles in the headwaters and connecting downstream with the YMT profiles. We thus have proposed a new model that satisfactorily integrates all available data by superposing the climatic cyclicity of fluvial erosion over a tectonically induced response of the drainage system that started with the propagation of knickpoints in the rivers from the periphery toward the interior of the uplifted region, followed by a gradual return of the profiles to equilibrium in the areas downstream of the front of the erosion wave. Moreover, we identified a particular behaviour of the migrating knickpoints that seem to undergo strong delays in their propagation at junctions with alluvial tributaries, which we tentatively ascribed to a possible transient response of the tributary by channel form modifications, until some threshold in trunk stream incision and local base level lowering is overcome and a knickpoint reforms and starts retreating in the tributary.

\section{References}

Attal M., Tucker G., Whittaker A., Cowie P. \& Roberts, G., 2008. Modeling fluvial incision and transient landscape evolution: Influence of dynamic channel adjustment. Journal of Geophysical Research 113F, F03013, doi: 10.1029/ 2007JF000893.

Beckers A., Bovy B. \& Demoulin, A., 2011. Knickpoint migration in a drainage network of the Ardennes, Western Europe: What happens at junctions? Earth Surface Processes and Landforms, submitted.

Berlin M. \& Anderson, $\boldsymbol{R}_{\text {., }}$ 2007. Modeling of knickpoint retreat on the Roan Plateau, western Colorado. Journal of Geophysical Research 112F, F03S06, doi: 10.1029/2006JF000553.

Bishop P., Hoey T., Jansen J. \& Artza, I., 2005. Knickpoint recession rate and catchment area: the case of uplifted rivers in Eastern Scotland. Earth Surface Processes and Landforms 30: 767-778.

Blum M. \& Törnqvist, T., 2000. Fluvial responses to climate and sea level change: a review and look forward. Sedimentology 47 (Suppl. 1): 2-48.

Boenigk W. \& Frechen, M., 2006. The Pliocene and Quaternary fluvial archives of the Rhine system. Quaternary Science Reviews 25: 550-574.

Bridgland, D., 2000. River terrace systems in north-west Europe: an archive of environmental change, uplift, and early human occupation. Quaternary Science Reviews 19: 1293-1303.

Bridgland, D. \& Westaway, R., 2008. Climatically controlled river terrace staircases: a worldwide Quaternary phenomenon. Geomorphology 98: 285-315.

Brunnacker, K. \& Boenigk, W., 1983. The Rhine valley between the Neuwied Basin and the lower Rhenish Embayment. In: Fuchs, K., Gehlen, K.v., Maelzer, H., Murawski \& H., Semmel, A. (eds): Plateau Uplift - The Rhenish Shield - A Case History. Springer, Berlin: 62-73.

Büdel, J., 1977. Klima-Geomorphologie. Gebrüder Bornträger, Berlin - Stuttgart, $304 \mathrm{p}$.

Camelbeeck, T. \& Meghraoui, M., 1998. Geological and geophysical evidence for large palaeoearthquakes with surface faulting in the Roer graben (northwestern Europe). Geophysical Journal International 132: 347-362.

Cordier, S., Harmand, D., Frechen, M. \& Beiner, M., 2006. Fluvial system response to Middle and Upper Pleistocene climate change in the Meurthe and Moselle valleys (Eastern Paris Basin and Rhenish Massif). Quaternary Science Reviews 25: $1460-1474$. 
Cordier, S., Frechen, M. \& Tsukamoto, S., 2010. Methodological aspects on luminescence dating of fluvial sands from the Moselle basin, Luxembourg. Geochronometria 35: 67-74.

Cornet, Y., 1995. L'encaissement des rivières ardennaises au cours du Quaternaire. In: Demoulin, A. (ed.): L'Ardenne. Essai de géographie physique, Dépt Géographie Physique, Université de Liège (Liège): 155-177.

Crosby, B. \& Whipple, K., 2006. Knickpoint initiation and distribution within fluvial networks: 236 waterfalls in the Waipaoa River, North Island, New Zealand. Geomorphology 82: 16-38.

Crosby, B., Whipple, K., Gasparini, N. \& Wobus C., 2007. Formation of fluvial hanging valleys: Theory and simulation. Journal of Geophysical Research 112F, F03S10, doi: 10.1029/2006JF000566.

Demoulin, A., 1995. Les surfaces d'érosion méso-cénozoïques en Ardenne-Eifel. Bulletin de la Société Géologique de France 166: 573-585.

Demoulin, A. \& Hallot, E., 2009. Shape and amount of the Quaternary uplift of the western Rhenish shield and the Ardennes (western Europe). Tectonophysics 474: 696-708.

Demoulin, A., Hallot, E. \& Rixhon, G., 2009. Amount and controls of the Quaternary denudation in the Ardennes massif (western Europe). Earth Surface Processes and Landforms 34: 1487-1496.

Demoulin, A., Beckers, A. \& Bovy, B., 2012. On different types of adjustment usable to calculate the parameters of the stream power law. Geomorphology 138: 203-208.

$\boldsymbol{E} \boldsymbol{k}, \boldsymbol{C} ., 1957$. Les terrasses de l'0urthe et de l'Amblève inférieures. Annales de la Société géologique de Belgique 80: 333-353.

Felder, W., Bosch, P. \& Bisschops, J., 1989. Geologische kaart van Zuid-Limburg en omgeving. Afzettingen van de Maas. Rijks Geologische Dienst, Heerlen, Nederland.

Garcia-Castellanos, D., Cloetingh, S. \& Van Balen, R., 2000. Modelling the Middle Pleistocene uplift in the Ardennes-Rhenish Massif: thermo-mechanical weakening under the Eifel? Global and Planetary Change 27: 39-52.

Gibbard, P. \& Lewin, J., 2009. River incision and terrace formation in the Late Cenozoic of Europe. Tectonophysics 474: 41-55.

Hoffmann, $\boldsymbol{R}_{\text {., }}$ 1996. Die quartäre Tektonik des südwestlichen Schiefergebirges begründet mit der Höhenlage der jüngeren Hauptterrasse der Mosel und ihrer Nebenflüsse. Bonner Geowissenschaftliche Schriften 19, 156 p.

Houtgast, R., Van Balen, R. \& Kasse, C., 2005. Late Quaternary evolution of the Feldbiss Fault (Roer Valley Rift System, the Netherlands) based on trenching and its potential relation to glacial unloading. Quaternary Science Reviews 24: 491-510.

Howard, A. \& Kerby, G., 1983. Channel changes in badlands. Geological Society of America Bulletin 94: 739-752.

Huxtable, J. \& Aitken, M., 1985. Thermoluminescence dating results for the Paleolithic site Maastricht-Belvédère. Mededelingen Rijks Geologische Dienst 39: 41-44.

Juvigné, E., 1979. L'encaissement des rivières ardennaises depuis le début de la dernière glaciation. Zeitschrift für Geomorphologie 23, 291-300.

Juvigné, E. \& Schumacker, $R ., 1985$. Données nouvelles sur l'âge de la capture de la Warche à Bévercé. Bulletin de la Société géographique de Liège 21: 3-11.

Juvigné, E. \& Renard, F., 1992. Les terrasses de la Meuse de Liège à Maastricht. Annales de la Société géologique de Belgique 115: 167-186.
Lenaz, D., Marciano, R., Veres, D., Dietrich, S. \& Sirocko, F., 2010. Mineralogy of the Dehner and Jungferweiher maar tephras (Eifel, Germany). Neues Jahrbuch Geologische Paläontologische Abhandlungen 257: 55-67.

Lewin, J. \& Gibbard, P., 2010. Quaternary river terraces in England: Forms, sediments and processes. Geomorphology 120: 293-311.

Loget, N. \& Van Den Driessche, J., 2009. Wave train model for knickpoint migration. Geomorphology 106: 376-382.

Losson, B. \& Quinif, Y., 2001. La capture de la Moselle: nouvelles données chronologiques par datations U/Th sur spéléothèmes. Karstologia 37: 29-40.

Meyer, W. \& Stets, J., 1998. Junge Tektonik im Rheinischen Schiefergebirge und ihre Quantifizierung. Zeitschrift der Deutschen geologischen Gesellschaft 149:359-379.

Meyer, W. \& Stets, J., 2007. Quaternary uplift in the Eifel area. In: Ritter, J. \& Christensen, U. (eds): Mantle plumes, A multidisciplinary approach, Springer: 369-378.

Negendank, J., 1978. Zur Känozoischen Geschichte von Eifel und Hunsrück. Sedimentpetrographische Untersuchungen im Moselbereich. Forschungen zur Deutscen. Landeskunde 211, 90 p.

Ouchi, S., 1985. Response of alluvial rivers to slow active tectonic movement. Geological Society of America Bulletin 96: 504-515.

Penck, A. \& Brückner, E., 1909. Die Alpen im Eiszeitalter. Tauchnitz, Leipzig, 3 vol., 1199 p.

Pissart, A., 1974. La Meuse en France et en Belgique. Formation du bassin hydrographique. Les terrasses et leurs enseignements. In: L'évolution quaternaire des bassins fluviaux de la Mer du Nord méridionale, Société Géologique de Belgique, Liège: 105-131.

Pissart, A. \& Juvigné, E., 1982. Un phénomène de capture près de Malmédy: la Warche s'écoulait autrefois par la vallée de l'Eau Rouge. Annales de la Société géologique de Belgique 105: 73-86.

Pissart, A., Harmand, D. \& Krook, L., 1997. L'évolution de la Meuse de Toul à Maastricht depuis le Miocène: corrélations chronologiques et traces des captures de la Meuse lorraine d'après les minéraux denses. Géographie physique et Quaternaire 51: 267-284.

Pouclet, A., Juvigné, E. \& Pirson, S., 2008. The Rocourt Tephra, a widespread 90-74 ka stratigraphic marker in Belgium. Quaternary Research 70: 105-120.

Quinif, Y., 1999. Karst et évolution des rivières: le cas de l'Ardennes. Geodinamica Acta 12: 267-277.

Ritter, J., Jordan, M., Christensen, U. \& Achauer, U., 2001. A mantle plume below the Eifel volcanic fields, Germany, Earth and Planetary Science Letters 186: 7-14. Rixhon, G. \& Demoulin A., 2010. Fluvial terraces of the Amblève: a marker of the Quaternary river incision in the NE Ardennes massif (Western Europe). Zeitschrift für Geomorphologie 54: 161-180.

Rixhon, G., Braucher, R., Bourlès, D., Siame, L., Bovy, B. \& Demoulin, A., 2011. Quaternary river incision in NE Ardennes (Belgium) - Insights from ${ }^{10} \mathrm{Be} /{ }^{26} \mathrm{Al}$ dating of river terraces. Quaternary Geochronology, 6: 273-284.

Schmincke, H., 2007. The Quaternary Volcanic Fields of the East and West Eifel (Germany). In: Ritter, J. \& Christensen, U. (eds): Mantle plumes, A multidisciplinary approach, Springer: 241-322.

Sklar, L. \& Dietrich, W., 1998. River longitudinal profiles and bedrock incision models: Stream power and the influence of sediment supply. In: Tinkler, K. \& Wohl, E., (eds): Rivers over rock: Fluvial processes in bedrock channels, Geophysical Monographies Series, 107, AGU (Washington D.C.): 237-260. 
Sklar, L. \& Dietrich, W., 2004. A mechanistic model for river incision into bedrock by saltating bed load. Water Resources Research 40, W06301, doi: 10.1029/2003WR002496.

Van Balen, R., Houtgast, R., Van der Wateren, F., Vandenberghe, J. \& Bogaart, $P ., 2000$. Sediment budget and tectonic evolution of the Meuse catchment in the Ardenness and the Roer Valley Rift System. Global and Planetary Change 27:113-129.

Van Balen, R., Busschers, F. \& Tucker, G., 2010. Modeling the response of the Rhine-Meuse fluvial system to Late Pleistocene climate change. Geomorphology 114, 440-452.

Van den Berg, M., 1996. Fluvial sequences of the Maas. A 10 Ma record of neotectonics and climate change at various time-scales. Landbouwuniversiteit Wageningen, $181 \mathrm{p}$.

Vandenberghe, J., 1993. Changing fluvial processes under changing periglacial conditions. Zeitschrift für Geomorphologie, Supplement Band 88: 17-28.

Vandenberghe, J., 1995a. Timescales, climate and river development. Quaternary Science Reviews 14: 631-638.

Vandenberghe, J., 1995b. The role of rivers in palaeoclimatic reconstruction. In: Frenzel, B., Vandenberghe, J., Kasse, C., Bohncke, S. \& Glaser, B. (eds): European River Activity and Climatic Change during the Lateglacial and early Holocene. Paläoklimaforschung 14: 11-19.

Vandenberghe, J., 2002. The relation between climate and river processes, landforms and deposits during the Quaternary. Quaternary International 91: 17-23.

Vandenberghe, J., 2003. Climate forcing of fluvial system development: an evolution of ideas. Quaternary Science Reviews 22: 2053-2060.

Vandenberghe, J., 2008. The fluvial cycle at cold-warm-cold transitions in lowland regions: A refinement of theory. Geomorphology 98: 275-284.

Whipple, K. \& Tucker, G., 1999. Dynamics of the stream-power river incision model: implications for height limits of mountain ranges, landscape response timescales, and research needs. Journal of Geophysical Research 104B: 17661-17674.

Whipple, K. \& Tucker, G., 2002. Implications of sediment-flux-dependent river incision models for landscape evolution. Journal of Geophysical Research 107B, 2039, doi: 10.1029/2000JB000044.

Wobus, C., Crosby, B. \& Whipple, K., 2006. Hanging valleys in fluvial systems: Controls on occurrence and implications for landscape evolution. Journal of Geophysical Research 111F, F02017, doi: 10.1029/2005JF000406.

Whittaker, A., Attal, M., Cowie, P., Tucker, G. \& Roberts, G., 2008. Decoding temporal and spatial patterns of fault uplift using transient river long profiles. Geomorphology 100: 506-526.

Ziegler, P. \& Dèzes, P., 2007. Cenozoic uplift of Variscan massifs in the Alpine foreland: Timing and controlling mechanisms. Global and Planetary Change 58: $237-269$ 